\title{
The November 2002 degassing event at Panarea Island (Italy): five months of geochemical monitoring
}

\author{
Bruno Capaccioni $\left({ }^{1}\right)\left({ }^{6}\right)$, Franco Tassi $\left({ }^{2}\right)\left({ }^{4}\right)$, Orlando Vaselli $\left({ }^{2}\right)\left({ }^{4}\right)$, Dario Tedesco $\left({ }^{3}\right)\left({ }^{5}\right)$ \\ and Piermaria Luigi Rossi $\left({ }^{6}\right)$ \\ (') Istituto di Vulcanologia e Geochimica, Università degli Studi di Urbino, Italy

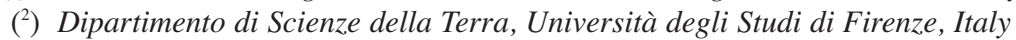 \\ (3) Dipartimento di Scienze Ambientali, Seconda Università degli Studi di Napoli, Caserta, Italy \\ $\left(^{4}\right)$ Istituto di Geoscienze e Georisorse, CNR, Firenze, Italy \\ $\left(^{5}\right)$ Istituto di Geologia Ambientale e Geo-Ingegneria, CNR, Roma, Italy \\ $\left({ }^{6}\right)$ Dipartimento di Scienze della Terra e Geologico-Ambientali, Università degli Studi di Bologna, Italy
}

\begin{abstract}
On 3rd November 2002, at about $3 \mathrm{~km}$ off-shore of Panarea Island (Aeolian Islands, Southern Italy), a series of gas vents suddenly and violently opened from the seafloor at the depth of 10-15 m, with an unusually high gas flux and superimposing on the already existing submarine fumarolic field. Starting from the 12th November 2002 a discontinuous geochemical monitoring program was carried out. The emissions consisted in an emulsion whose liquid phase derived from condensation of an uprising vapor phase occurring close to the fluid outlets without significant contamination by seawater. The whole composition of the fluids was basically $\mathrm{H}_{2} \mathrm{O}-$ and $\mathrm{CO}_{2}$-dominated, with minor amounts of typical «hydrothermal» components (such as $\mathrm{H}_{2} \mathrm{~S}, \mathrm{H}_{2}, \mathrm{CO}$ and light hydrocarbons), atmospheric-related compounds, and characterized by the occurrence of a significant magmatic gas fraction (mostly represented by $\mathrm{SO}_{2}, \mathrm{HCl}$ and $\mathrm{HF}$ ). According to the observed temporal variability of the fluid compositions, between November and December 2002 the hydrothermal feeding system was controlled by oxidizing conditions due to the input of magmatic gases. The magmatic degassing phenomena showed a transient nature, as testified by the almost complete disappearance of the magmatic markers in a couple of months and by the restoration, since January 2003, of the chemical features of the existing hydrothermal system. The most striking feature of the evolution of the «Panarea degassing event» was the relatively rapid restoration of the typical reducing conditions of a stationary hydrothermal system, in which the $\mathrm{FeO} / \mathrm{Fe}_{1.5} \mathrm{O}$ redox pair of the rock mineral phases has turned to be the dominating redox controlling system.
\end{abstract}

Key words Aeolian Islands - Panarea - submarine fumaroles - gas chemistry - geochemical monitoring

Mailing address: Dr. Bruno Capaccioni, Istituto di Vulcanologia e Geochimica, Università degli Studi di Urbino, Loc. Crocicchia, 61029 Urbino, Italy; e-mail: b.capaccioni@uniurb.it

\section{Introduction}

On November 32002 at least three large and whitish plumes suddenly appeared at the sea surface about $3 \mathrm{~km}$ eastward of Panarea Island (Aeolian Archipelago, Southern Italy), in an area characterized by a relatively shallow sea (10-15 $\mathrm{m}$ deep) and by the presence of emerging reefs of different size, roughly forming an elliptical shape (fig. 1). The phenomenon proved to be the surface expression of huge gas columns emerging from the sea floor as a mix- 
ture of gas, fine-grained sediments and colloidal sulphur, in an area previously characterized by a gentle bubbling sub-marine fumarolic field (Gabbianelli et al., 1990; Italiano and Nuccio, 1991; Calanchi et al., 1995). A particularly large plume occurred a few tens of meters SE of Bottaro reef (hereafter named Bottaro 1). According to the size of the «crater» depression produced (about $20 \times 14 \mathrm{~m}$ wide and $10 \mathrm{~m}$ deep), the event was probably the result of a sort of submarine «gas blast».

In order to define the nature of these new gas emissions and their temporal evolution, a first gas sampling campaign was carried out starting on November 12 and followed by three samplings, almost on a monthly basis, until March 2003.

\section{Geological and volcanological setting}

Panarea is the smallest island $\left(3.3 \mathrm{~km}^{2}\right)$ of the Aeolian Archipelago (i.e. the subaereal portion of the Aeolian Volcanic District - AVD). The AVD is a ring-like volcanic arc consisting of 7 islands and 10 seamounts, and it constitutes about $200 \mathrm{~km}$ of the inner side of the Peloritanian-Calabrian orogenic belt (Boccaletti and Manetti, 1978; Beccaluva et al., 1982, 1985; Gabbianelli et al., 1990; Calanchi et al., 2002). The dynamics of this arc (which is located along regional NS-, EW- and NE-SW-oriented fault systems) is determined by tectonics through some faults that are still active (Gasparini et al., 1982; Lanzafame and Rossi, 1984). The AVD is characterized by a subduction-related magmatism that ranges from calcalkaline to shoshonite products. The volcanic activity has taken place almost entirely since the Quaternary, $400 \mathrm{Kyr}$ up to the present (Calanchi et al., 2002).

The morphology of the sea floor, as defined by the $100 \mathrm{~m}$ isobaths, resembles that of a volcanic complex characterized by a multi-phase evolution (Gabbianelli et al., 1986, 1990). After the growth of a central apparatus, centered in the island and in the submarine surroundings, volcanic activity occurred within the eastern area through a NE-SW fissure system.

According to radiometric ages, the subaereal portion grew in a short period of time (150-
$100 \mathrm{Kyr})$. After $50 \mathrm{Kyr}$ of quiescence, the activity resumed with the emplacement of the endogenous dome of Basiluzzo, located NE of Panarea, along the Panarea-Stromboli tectonic line (NE-SW fault system). Between Basiluzzo and Panarea, some small islets (Dattilo, Bottaro, Lisca Bianca, Panarelli and Lisca Nera) (Calanchi et al., 1999a,b) are arranged along a circular rim about $1 \mathrm{~km}$ in diameter. The area defined by the islets has a crater-like shape, with a maximum depth of $30 \mathrm{~m}$, and is characterized by an important gravimetric anomaly

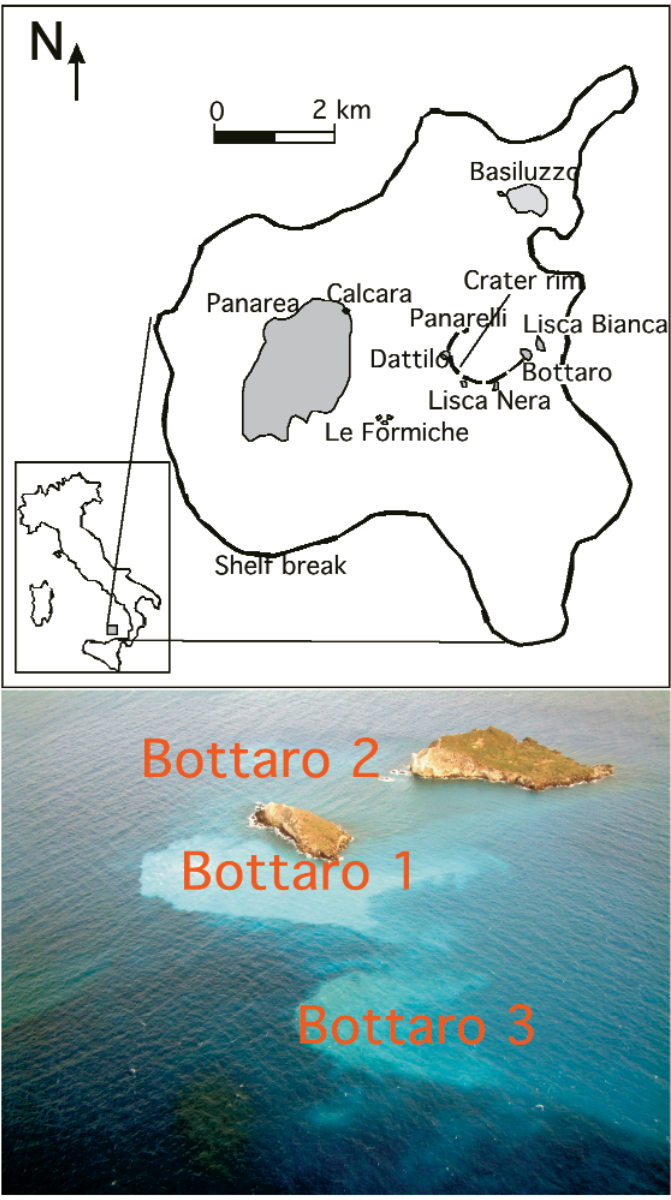

Fig. 1. Map of Panarea Island with the locations of Calcara, Bottaro 1, Frattura, Bottaro 2 and Bottaro 3 gas discharges. 


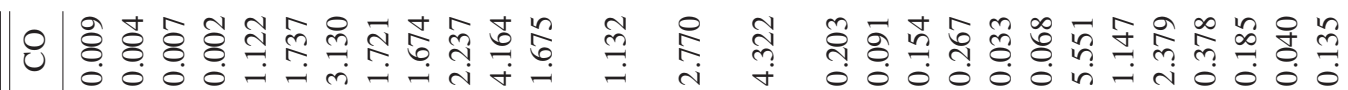
I

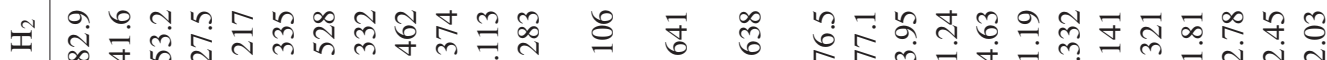

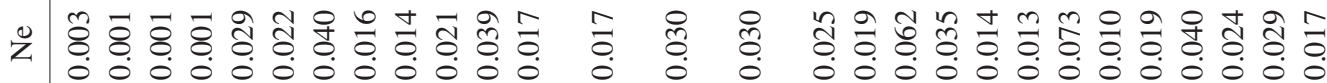

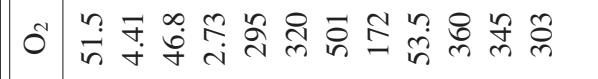

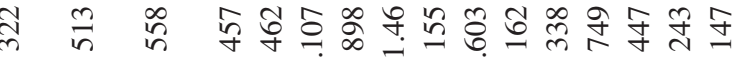

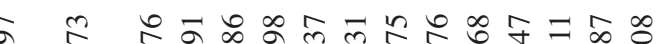

○

능 王 $m-A \mathrm{n}-\mathrm{C}-m-\mathrm{n}-$

윌

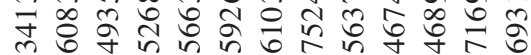
zด zด

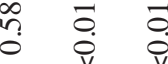

กิ

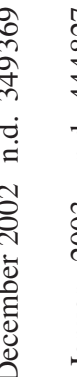

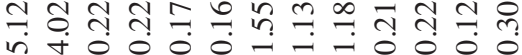
约

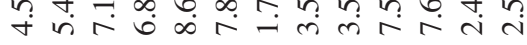
능 -

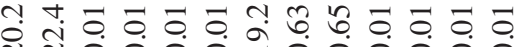
กิ

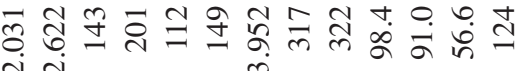
के 守市令守 迆

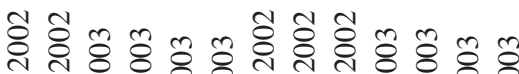

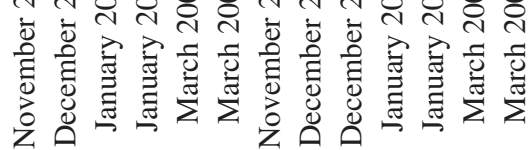
N N N N $n m m m m m m$

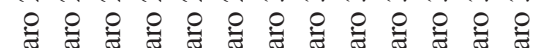

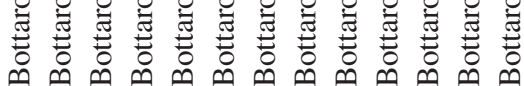


(Bonasia et al., 1973; Calanchi et al., 1999b), whose interpretation is still a matter of debate. This area is also affected by a strong exhalative and hydrothermal activity known since the Roman Age. The oldest detailed descriptions of such activities date back to the 18th century (De Dolomieu, 1783). On the other hand, the first modern descriptions of this hydrothermal system were given by Gabbianelli et al. (1990), Italiano and Nuccio (1991) and Calanchi et al. (1995).

\section{Sampling and analytical methods}

Fluids were collected four times between November 2002 and March 2003 (table I) from four different sites (fig. 1): a) Bottaro 1, which includes both Bottaro 1 and Bottaro Frattura samples, located a few tens of meters from the western margin of the Bottaro islet and consisting of a central huge $15 \mathrm{~m}$ deep emission discharging from a crater-shaped depression on the seafloor and minor diffuse bubbling all around; b) Bottaro 2 is a group of gas discharges close to the NW corner of Bottaro islet at a depth of 7$12 \mathrm{~m}$; c) Bottaro 3 consists of diffuse gas bubbling with relatively low flux and discharging SE of Bottaro islet in an area of $100-200 \mathrm{~m}^{2}$; d) Calcara is a pre-existing, weak fumarolic discharge located at about $10 \mathrm{~m}$ inland close to the eastern shore of Panarea Island.

The gas emissions from Bottaro 1 vent have the largest flux of the entire fumarolic field, although a correct estimation of the total flux rate (not carried out in the present study), significantly decreased since December 2002, is difficult to computed.

Samples were collected in pre-weighted and pre-evacuated 50-ml thorion-tapped glass tubes, partially filled with $20 \mathrm{ml}$ of a solution $0.15 \mathrm{M} \mathrm{Cd}(\mathrm{OH})_{2}$ and $4 \mathrm{M} \mathrm{NaOH}$, connected to a plastic funnel positioned up-side-down over the uprising bubbles. To avoid contamination by seawater, the silicon tube between the funnel and the collecting glass tube was filled with Milli-Q water and isolated from seawater by a plastic plug (fig. 2). The plug was removed only after the complete evacuation of the seawater contained in the funnel by gases.
Acidic gases $\left(\mathrm{CO}_{2}, \mathrm{SO}_{2}, \mathrm{H}_{2} \mathrm{~S}, \mathrm{HCl}, \mathrm{HF}\right)$ and water were trapped in the alkaline solution. During sampling, elemental sulphur precipitates, $\mathrm{SO}_{2}$ dissolves in the alkaline solution, whereas $\mathrm{H}_{2} \mathrm{~S}$ reacts with $\mathrm{Cd}^{2+}$ to form insoluble CdS.

Inert gases $\left(\mathrm{N}_{2}, \mathrm{O}_{2}, \mathrm{CO}, \mathrm{H}_{2}, \mathrm{He}, \mathrm{Ar}, \mathrm{Ne}\right.$, $\mathrm{CH}_{4}$ ), collected in the head-space, were analyzed with a gas-chromatograph (Shimadzu 15a), equipped with a Thermal Conductivity Detector. During the analysis, separation of $\mathrm{H}_{2}$, $\mathrm{He}$ and Ne peaks was obtained by using a $9 \mathrm{~m}$ long molecular sieve column, at a temperature of $30^{\circ} \mathrm{C}$. To allow a complete separation of Ar$\mathrm{O}_{2}$ peaks, the temperature was lowered to $0^{\circ} \mathrm{C}$ by means of cryogenic equipment (Shimadzu CRG-15) fed by liquid $\mathrm{CO}_{2}$.

After analysis of the inert gases, the solution was separated by centrifugation from the solid precipitates and oxidized with $\mathrm{H}_{2} \mathrm{O}_{2}$ to convert $\mathrm{SO}_{2}$ to $\mathrm{SO}_{4}^{2-}$ that was then analyzed using a Dionex DX100 ion-chromatograph equipped with an Ionpac AS9-HC column. CdS in the solid phase was dissolved and oxidized with $\mathrm{H}_{2} \mathrm{O}_{2}$ and then analyzed by ion-chromatogra-

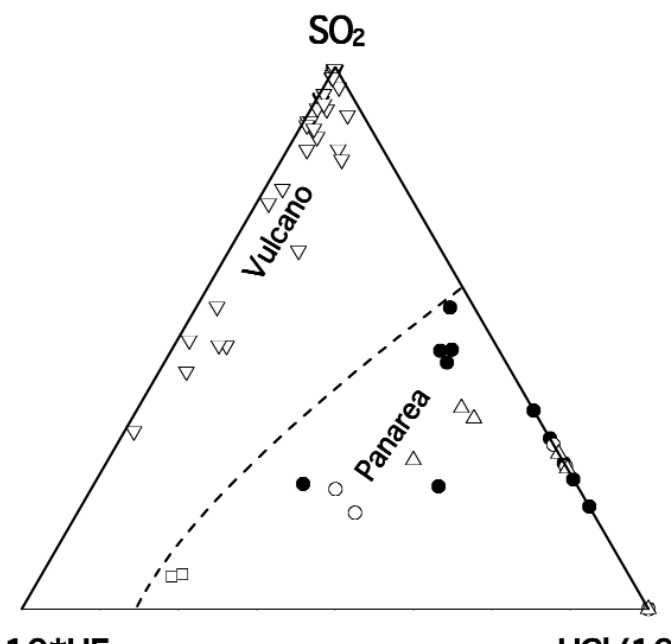

$10 * \mathrm{HF}$

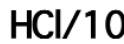

Fig. 2. $\mathrm{HCl} / 10-\mathrm{HF} * 10-\mathrm{SO}_{2}$ ternary diagram. Black circles: Bottaro 1 and Frattura gas discharges; open squares: Calcara gas discharge; open circles: Bottaro 2 gas discharges; open triangles: Bottaro 3 gas discharges. 
phy as $\mathrm{SO}_{4}^{2-} \cdot \mathrm{S}^{0}$ was extracted from residual precipitate with $\mathrm{CCl}_{4}$ and oxidized to $\mathrm{S}_{2} \mathrm{I}_{2}$ with the addition of KI. Finally, sulphur of $\mathrm{S}_{2} \mathrm{I}_{2}$ was oxidized to $\mathrm{SO}_{4}{ }^{2-}$ by $\mathrm{KBrO}_{3}$ and analyzed by ion chromatography (Montegrossi et al., 2001). $\mathrm{CO}_{2}$ in the caustic solution was analyzed by acidimetric titration with $0.5 \mathrm{~N} \mathrm{HCl}$ solution. $\mathrm{F}^{-}$ and $\mathrm{Cl}^{-}$, in the alkaline solution, were also analyzed by ion-chromatography with the Ionpac AS9-HC column. To permit the complete separation of $\mathrm{F}^{-}$and $\mathrm{OH}^{-}$peaks a $1 \mu \mathrm{mol} \mathrm{Na} \mathrm{NaO}_{3}$ solution was used as eluent phase instead of the $10 \mu \mathrm{mol} \mathrm{Na} \mathrm{CO}_{3}$ solution, the latter being commonly utilized for ion-chromatographic analysis of anions.

Analytical precision was $<1 \%$ for major gas components and $<5 \%$ for minor and trace compounds.

\section{Volatile acid compounds or contamination by seawater? Some critical considerations}

Before providing any interpretation of the collected data it is useful to discuss what they really represent. As will be discussed below, the most impressive features of the gases collected on November and December 2002 are the presence of chloride, fluoride, and sulphite, and the relatively high water contents, exceeding what would be expected in fluids at $50^{\circ} \mathrm{C}$ and 2.5 bar (i.e. the values of temperature and pressure during sampling). A possible persistence of acid species $\left(\mathrm{SO}_{2}, \mathrm{HF}\right.$ and $\mathrm{HCl}$; table $\left.\mathrm{I}\right)$ in gases discharging from the sea bottom clearly conflicts with the high solubility in seawater of these compounds. This would imply a severe internal disequilibrium of the emerging gases that can only be explained by the huge gas flux, particularly at Bottaro 1 vent. Despite the specific sampling procedures adopted to avoid seawater contamination, the problem of introducing seawater droplets or micro-droplets has been considered and discussed accordingly. The measured $\mathrm{SO}_{2} / \mathrm{HCl}$ ratios of the collected gas samples range from 0.08 to 0.19 and from 0.06 to 0.37 on November 2002 and December 2002, respectively. Since the $\mathrm{SO}_{2} / \mathrm{HCl}$ ratio of normal seawater is 0.14 , the reasonable suspicion of the occurrence of seawater contamination instead of the introduction of volatile acid compounds into the sampling device cannot be ruled out. Nevertheless, volcanic gases with $\mathrm{SO}_{2} / \mathrm{HCl}$ ratios $<1$ are not so uncommon. Some crater emissions at El Chichon volcano (Tassi et al., 2003) have $\mathrm{SO}_{2} / \mathrm{HCl}$ ratios in the range of 0.07 0.64 , whereas up to $0.007 \mathrm{SO}_{2} / \mathrm{HCl}$ ratios have been measured at Usu volcano (Symonds et al., 1996). Moreover, the observed significant positive correlation between the two gas compounds is not a critical factor since it can be due to either seawater contamination or input of acid species into the sampling device. However, according to the relatively high $\mathrm{Br}^{-}$content in seawater $(65 \mathrm{mg} / \mathrm{L})$, in the case of seawater contamination the collected $\mathrm{NaOH}$ solutions of Bottaro 1 samples collected on December 2002 should have at least $1 \mathrm{mg} / \mathrm{L}$ of $\mathrm{Br}^{-}$, well above its detection limit $(0.01 \mathrm{mg} / \mathrm{L}$; table I). In addition, together with the absolute absence of $\mathrm{Br}^{-}$, it is noteworthy to point out the occurrence of high $\mathrm{F}^{-}$contents in spite of its relatively low content in seawater $(1 \mathrm{mg} / \mathrm{L})$. A further critical factor is provided by sulphur speciation analytically observed in the $\mathrm{NaOH}$ solution of gas samples. Besides the $\mathrm{H}_{2} \mathrm{~S}$ fraction, precipitated as $\mathrm{CdS}$, and the elemental sulphur, collected as residual precipitate (see above), $\mathrm{SO}_{3}{ }^{2-}$, that can only be explained by a direct collection of gaseous $\mathrm{SO}_{2}$, is the prevailing sulphur compound before the addition of $\mathrm{H}_{2} \mathrm{O}_{2}$ to the $\mathrm{NaOH}$ solution. This seems to definitively exclude contamination by seawater. The dramatic drop of seawater $p H$ (see below), the corrosion effect on shells of foraminifers in the surrounding areas (Panieri et al., 2003), other than skin irritation reported by the scuba-divers represent convincing clues of the presence of highly acidic species in thermal fluid discharges.

The excess of water clearly conflicts with the expected «instantaneous» condensation of water vapour at $50^{\circ} \mathrm{C}$ and 2.5 bar. It seems reasonable to assume that water vapour condensed close to the sampling point and the condensation could have been transported by the gas flux as micro-droplets into the sampling device, together with acid species partially or totally dissolved in it (as suggested by Chiodini, pers. comm.). Thus, the detected chloride, fluoride and sulphite contents could derive, at least par- 
tially, from the condensed phase collected during sampling instead of directly from the gas phase.

Hence, we conclude that the acid gas species, characterizing the chemical composition of submarine gases discharged close to Panarea Island on November and December 2002, were mostly dissolved in the condensed phase before the introduction into the sampling device, without any significant contamination by normal or chemically modified seawater.

\section{The November 2002 gas composition}

Following the above mentioned considerations, the presence of variable amounts of water-soluble acid species ( $\mathrm{HF}, \mathrm{HCl}$ and $\mathrm{SO}_{2}$ ) in sampled gas discharges requires prevailing dry conditions of the fluids up to shallow depths, other than a severe disequilibrium between the submarine gas discharges and seawater. As already stated, this can only be explained by the observed huge gas flux, able to minimize chemical and physical interactions between the emerging fluids and the surrounding environment.

Analytical data for major, minor and trace gas compounds are listed in table I. The highest outlet temperature, measured as close as possible to the gas vents and probably representing a weighted mean between seawater and fluid temperature, was $50^{\circ} \mathrm{C}$, with $\mathrm{pH}$ values ranging between 5.0 and 5.5 (three units lower with respect to normal seawater; table I). Simultaneous measurements at La Calcara gas discharge (fig. 1) revealed a temperature range of 95$99^{\circ} \mathrm{C}$, in agreement with what was observed by Calanchi et al. (1995).

On November 2002, besides of the occurrence of water soluble acids, the gas composition of the submarine gas discharges was characterized by the prevalence of $\mathrm{H}_{2} \mathrm{O}$ (up to 710000 $\mu \mathrm{mol} / \mathrm{mol}$ ), $\mathrm{CO}_{2}$ (up to $650000 \mu \mathrm{mol} / \mathrm{mol}$ ), $\mathrm{N}_{2}$ and $\mathrm{H}_{2} \mathrm{~S}$ (up to 6100 and $4500 \mu \mathrm{mol} / \mathrm{mol}$, respectively). $\mathrm{H}_{2}$ and $\mathrm{CO}$ contents have a large compositional variability in terms of space, ranging from 0.0076 to $0.13 \mu \mathrm{mol} / \mathrm{mol}$ and from 0.2 to $5.6 \mu \mathrm{mol} / \mathrm{mol}$, respectively. Concerning the soluble acids, the already mentioned prevalence of

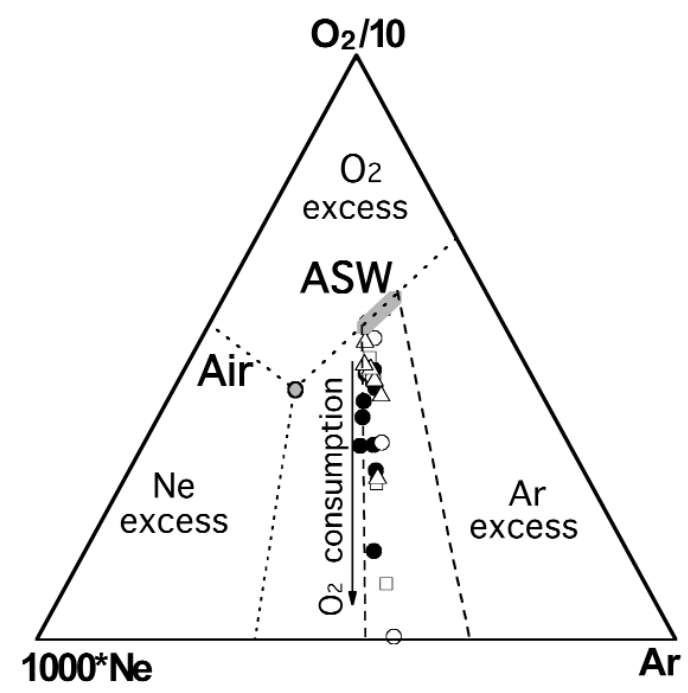

Fig. 3. $\mathrm{Ar}-\mathrm{O}_{2} / 10-\mathrm{Ne}^{*} 1000$ ternary diagram. Air and Air Saturated Water (ASW) compositions are reported. Black circles: Bottaro 1 and Frattura gas discharges; open squares: Calcara gas discharge; open circles: Bottaro 2 gas discharges; open triangles: Bottaro 3 gas discharges.

$\mathrm{HCl}$ over $\mathrm{SO}_{2}$ with respect to the typical compositions of the acid-bearing subaereal gases from Vulcano crater (fig. 2) could be related to the «stripping» of $\mathrm{HCl}$ from an acidified chlorinerich seawater (Symonds et al., 2001). Simple thermodynamic calculations based on the following equilibrium reactions:

$$
\mathrm{HCl}_{\mathrm{aq}}=\mathrm{Cl}^{-}+\mathrm{H}^{+}
$$

and

$$
\mathrm{HCl}_{g}=\mathrm{HCl}_{\mathrm{aq}}
$$

allow us to obtain a $P_{\mathrm{HCl}}$ in the range of those measured (4-12 mbar) by stripping $\mathrm{HCl}$ from seawater at $100^{\circ} \mathrm{C}$ and $p H=2$, conditions becoming less severe if we consider halite saturated solutions and/or temperature in excess of $100^{\circ} \mathrm{C}$.

The relative contents of $\mathrm{O}_{2}-\mathrm{Ar}-\mathrm{Ne}$ (fig. 3) clearly point to an atmospheric origin for these compounds through degassing of air saturated and heated seawater. Moreover, the trend to- 
wards the Ar-Ne side suggests a variable $\mathrm{O}_{2}$ consumption that seems to increase from November 2002 to March 2003.

\section{Temporal variations}

Between November 2002 and March 2003 the monitored submarine gas exhalations displayed a complex combination of temporal and spatial changes of their chemical compositions. The temporal variations of $\mathrm{H}_{2} \mathrm{O}$ and $\mathrm{CO}_{2}$ contents measured at Bottaro 1 and the $\mathrm{H}_{2} \mathrm{O}$ and $\mathrm{CO}_{2}$ values calculated according to the method of Chiodini and Cioni (1989) are reported in fig 4. The $\mathrm{H}_{2} \mathrm{O} / \mathrm{CO}_{2}$ ratios progressively decreased from November 2002 to March 2003: after January 2003 the gas mixture became $\mathrm{CO}_{2}$-dominated. The comparison between calculated and measured contents of $\mathrm{H}_{2} \mathrm{O}$ and $\mathrm{CO}_{2}$ suggests that in November and, partly, in December 2002, the relative amounts of collected water was not so different from those calculated at the re-equilibra-

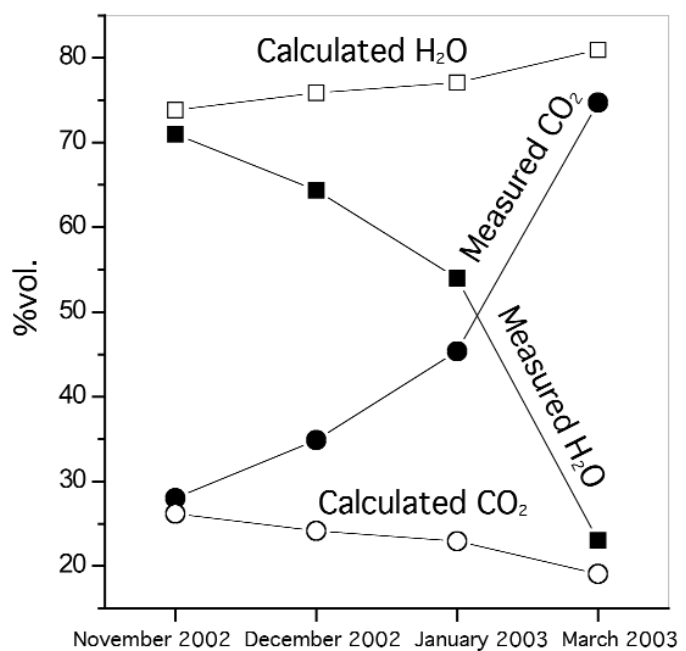

Sampling date

Fig. 4. Temporal variation of $\mathrm{CO}_{2}$ and $\mathrm{H}_{2} \mathrm{O}$ contents of Bottaro 1 and Frattura gas discharges (mean values) between November 2002 and March 2003. Calculated $\mathrm{CO}_{2}$ and $\mathrm{H}_{2} \mathrm{O}$ concentrations (Chiodini and Cioni, 1989) are reported.

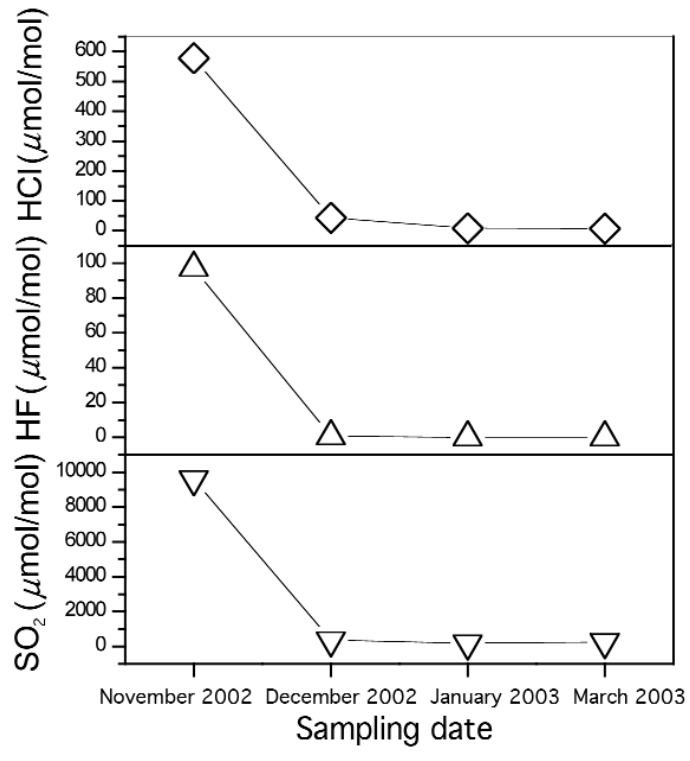

Fig. 5. Temporal variation of $\mathrm{HCl}, \mathrm{HF}$ and $\mathrm{SO}_{2}$ contents of Bottaro 1 and Frattura gas discharges (mean values) between November 2002 and March 2003.

tion zone, while a significant removal of the condensed phase seems have occurred from January 2003. Between November and December 2002, water-soluble acid species $\left(\mathrm{HCl}, \mathrm{HF}\right.$ and $\left.\mathrm{SO}_{2}\right)$ also underwent a sharp decrease (fig. 5), closely approaching the analytical detection limits. Such a behaviour recorded at Bottaro 1 area is in agreement with the expected trends for a progressive increase in the seawater/gas ratio along the whole fracture feeding system, as suggested by Symonds et al. (2001). The progressive disappearance of water-soluble acid species and collected water correspond to an increase in vapour phase condensation, possibly related to with the perceptible decrease of the gas flux at Bottaro 1 vent. Binary diagrams in fig. 6a,b report the expected trends (calculated according to the method suggested by Chiodini et al., 1996) for $\mathrm{H}_{2}$ and $\mathrm{SO}_{2}$ versus $\mathrm{He}$ at various degrees of gas dissolution in water, starting from the mean composition of the Bottaro 1 gas sample collected in November 2002. Both $\mathrm{H}_{2}$ and $\mathrm{He}$ (fig. 6a), due to their very low solubility on seawater, should display an in- 

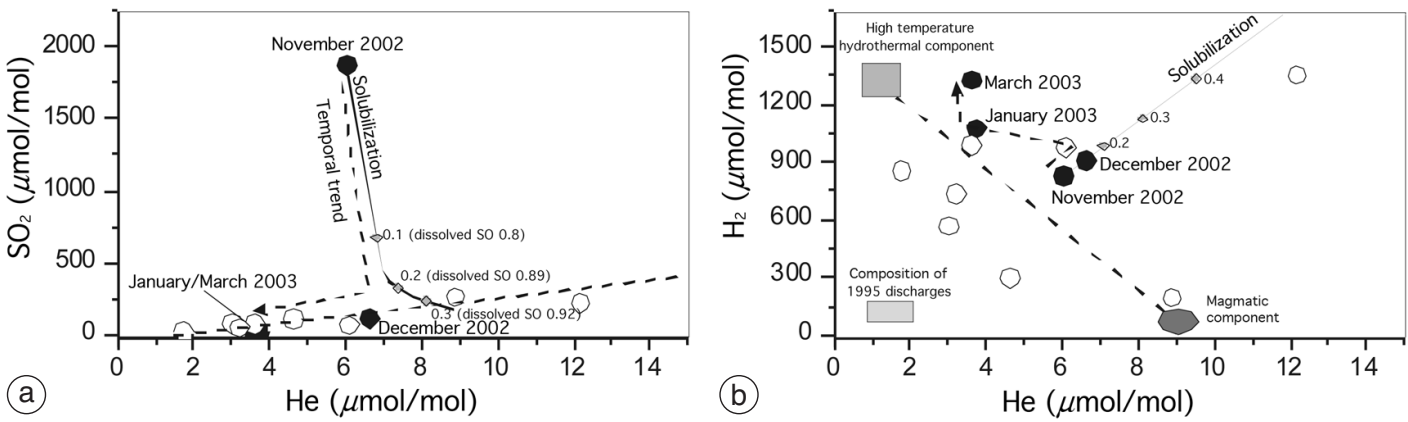

Fig. 6a,b. $\mathrm{H}_{2}$ versus $\mathrm{He}$ (a) and $\mathrm{SO}_{2}$ versus $\mathrm{He}$ (b) diagrams. Expected trends for simple solubilization process are reported. Black circles: mean values of gas samples collected in November 2002, December 2002, January 2003 and March 2003 at Bottaro 1 and Frattura gas discharges; open circles: gases sampled in December 2002 at Bottaro 1, Frattura, Bottaro 2 and Bottaro 3 gas discharges.

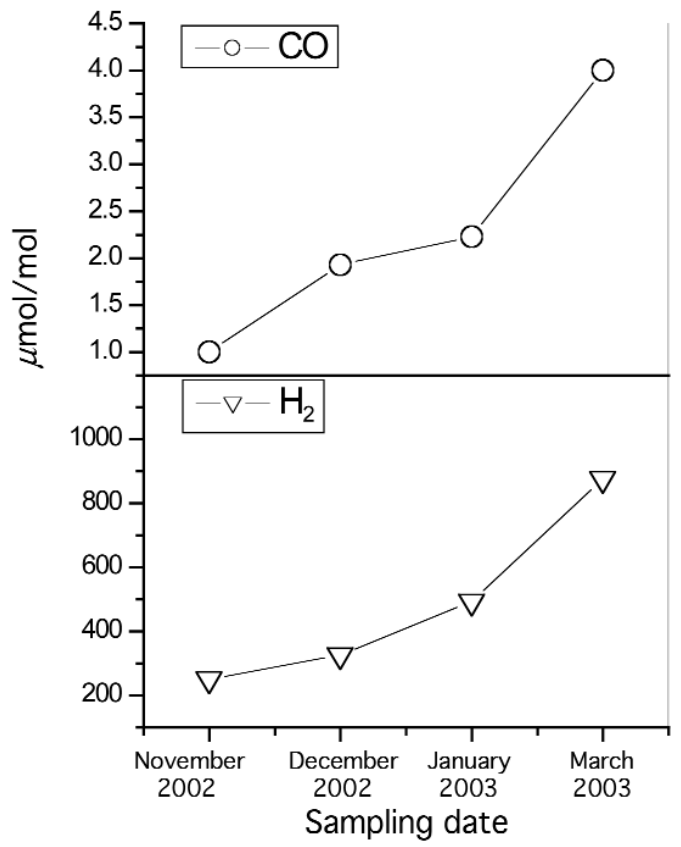

Fig. 7. Temporal variation of $\mathrm{H}_{2}$ and $\mathrm{CO}$ contents of Bottaro 1 and Frattura gas discharges (mean values) within the period November 2002-March 2003.

crease as dissolution proceeds. Although the mean compositions of Bottaro 1 fluid discharge (closed circles; fig. 6a) sampled in November and December 2002 actually followed the expected dissolution trend, samples collected after January 2003 dramatically shifted towards an $\mathrm{H}_{2}$-rich and He-poor end-member. Similarly, $\mathrm{SO}_{2}$ versus $\mathrm{He}$ contents (fig. 6b) at Bottaro 1 seem to be controlled by dissolution and liquid separation only in November and December 2002, while, in the following months, the trend moved towards an apparent $\mathrm{SO}_{2}$-poor end-member. Moreover, the composition of the whole gas discharges collected in December 2002 (open circles; fig. 6a), able to describe the spatial evolution of the chemical characteristics of the system, followed the same temporal pattern shown by Bottaro 1 in the period January-March 2003. Thus, the distribution of samples in fig. 6a,b seems to define a two-component mixing process consisting of: i) a $\mathrm{H}_{2}$-rich/ /He-poor (hydrothermal) and ii) a $\mathrm{H}_{2}$-poor/ /He-rich (residual magmatic?) end-member. This seems to represent the main controlling mechanism also in terms of spatial variability.

Figure 7 provides further insights into the temporal evolution of low water-soluble, redoxand temperature-dependent chemicals at Bottaro 1 in the period November 2002-March 2003. In March 2003, $\mathrm{H}_{2}$ content was almost an order of magnitude higher with respect to the values measured in November and December 2002. Also $\mathrm{CO}$ showed a concomitant increase in its contents (1-2 to $4-5 \mu \mathrm{mol} / \mathrm{mol}$; table I). These compositional changes cannot only be explained in terms of a simple balance between the two different end-members. Temporal changes in the 
chemical-physical properties of the hydrothermal reservoir feeding the submarine discharge system, such as an increase in temperature and/or reducing conditions, must be invoked. Figure 8 plots $\mathrm{CO}$ and $\mathrm{H}_{2}$ concentrations versus $\mathrm{H}_{2} \mathrm{~S} / \mathrm{Ar}$ ratios. $\mathrm{H}_{2} \mathrm{~S}$ is a temperature- and redox-dependent chemical species that forms a redox pair with $\mathrm{SO}_{2}$ and equilibrates with the $\mathrm{H}_{2} / \mathrm{H}_{2} \mathrm{O}$ pair typically at magmatic conditions (Giggenbach, 1987, 1996; Giggenbach and Glover, 1992). Due to both the chemical inertia and the very low water solubility of Ar, the abrupt increase in $\mathrm{H}_{2} \mathrm{~S} / \mathrm{Ar}$ ratios measured in March 2003 cannot be explained by simple passive enrichment during dissolution processes. Since $\mathrm{H}_{2} \mathrm{~S}$ is favoured by decreasing temperatures and increasing reducing conditions, its positive correlation with $\mathrm{CO}$ and $\mathrm{H}_{2}$ (favoured by the increase of both temperature and reducing conditions of the system) suggests that redox conditions between January and March 2003 had a fundamental role to control the chemical variations recorded at the surface.

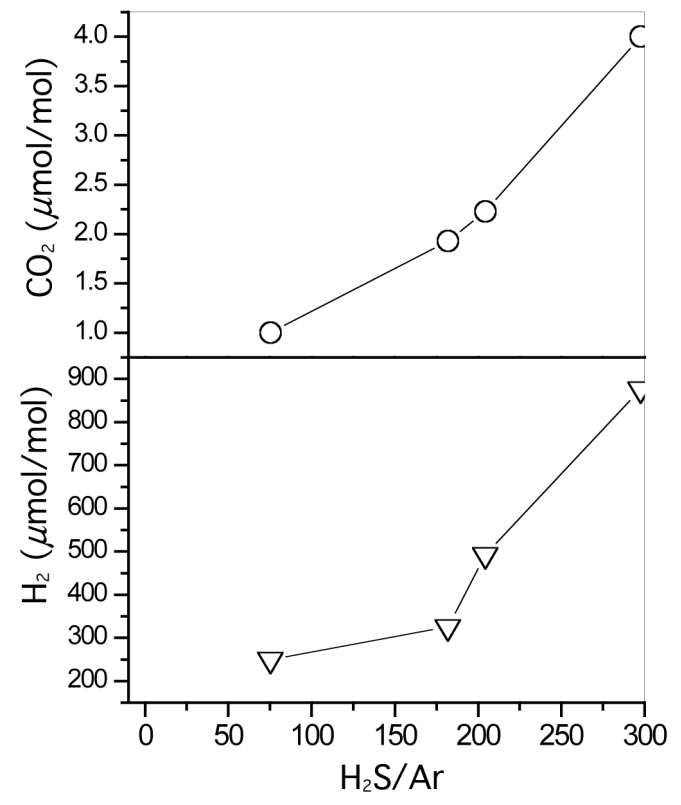

Fig. 8. $\mathrm{H}_{2}$ versus $\mathrm{H}_{2} \mathrm{~S} / \mathrm{Ar}$ and $\mathrm{CO}$ versus $\mathrm{H}_{2} \mathrm{~S} / \mathrm{Ar}$ diagrams of Bottaro 1 and Frattura gas discharges (mean values).

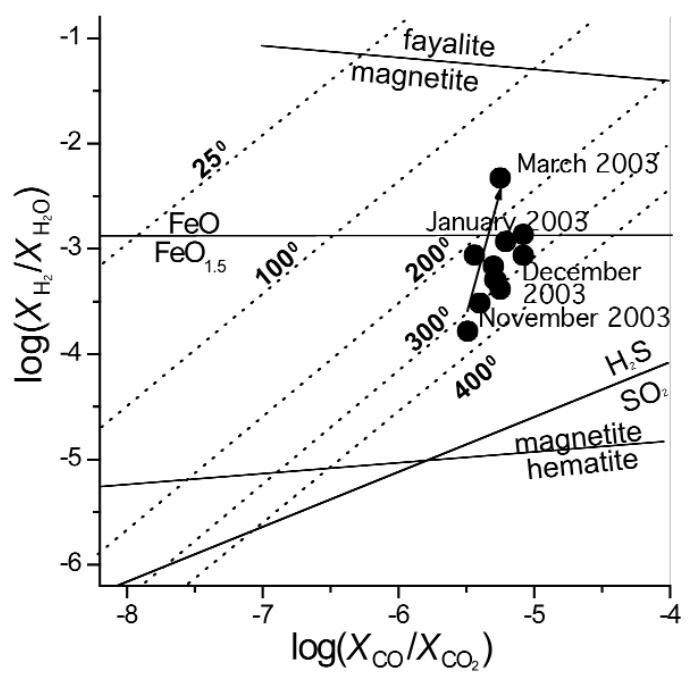

Fig. 9. $\log \left(\mathrm{CO} / \mathrm{CO}_{2}\right)$ versus $\log \left(\mathrm{H}_{2} / \mathrm{H}_{2} \mathrm{O}\right)$ diagram of Bottaro 1 and Frattura gas discharges. Rock (HM, $\mathrm{FM}$ and $\mathrm{GT})$ and gas $\left(\mathrm{SO}_{2} / \mathrm{H}_{2} \mathrm{~S}\right)$ redox buffers are reported.

\section{Concluding remarks}

The November 2002 degassing event occurring close to Panarea Island was supplied by an uprising $\mathrm{SO}_{2}$-bearing fluid of possible magmatic origin, variously mixed with a «transient», rapidly evolving hydrothermal fluid. In November and partly in December 2002, both fluids were chemically recognizable. The whole emitted fluid was possibly a sort of emulsion, made up of a mixture of gas and micro-droplets of condensation containing ions from acid species dissolution, dragged along the ascending conduits by the extremely high gas flux. According to the temporal variation of the fluid compositions recorded between November 2002 and March 2003 two main steps on the evolution of the feeding system can be recognized. The first step, occurring between November and December 2003, was dominated by a selective dissolution of the chemical species, mostly affecting the «magmatic» components, leading to a passive enrichment of the less soluble compounds. The second step, that took place after January 2003, appears to be almost completely dominated by the hydrothermal 
component which undergoes a rapid chemical evolution of its feeding system. In the Bottaro 1 area this chemical evolution can be well summarized by the $\mathrm{H}_{2} / \mathrm{H}_{2} \mathrm{O}$ versus $\mathrm{CO} / \mathrm{CO}_{2}$ binary diagram (fig. 9). The samples appear to be arranged along a trend which from November 2002 to March 2003 moved towards a lower temperature (from 300 to $200^{\circ} \mathrm{C}$ ) and towards increasing reducing conditions. As previously discussed, in the period between November and December 2002 the partial condensation of water vapour did not significantly modify the gas/water ratios observed, while it played a crucial role after January 2003. In any case, it seems that in November 2002 the feeding hydrothermal system was characterized by prevailing oxidizing conditions closer to «magmatic» ones (characterized by the influence of the $\mathrm{H}_{2} \mathrm{~S} / \mathrm{SO}_{2}$ redox buffer), shifting towards more reducing conditions starting from January 2003 and reaching a final rock-dominated redox state typical of a «stabilized» hydrothermal system starting from March 2003.

\section{Acknowledgements}

This work was financially supported by GNV-INGV (Gruppo Nazionale Vulcanologia). Many thanks are due to Mario Cosenza for his help during the diving campaigns at Panarea. Giovanni Chiodini is thanked for the stimulating discussions.

\section{REFERENCES}

Beccaluva, L., P.L. Rossi and G. Serri (1982): Neogene and recent volcanism of the Southern Tyrrhenian-Sicilian area: implications for the geodynamics evolution of the Calabrian Arc, Earth Evol. Sci., 3, 222-238.

Beccaluva, L., G. Gabbianelli, F. Lucchini, P.L. Rossi and C. SAVELli (1985): Petrology and K/Ar ages of volcanoes dredged from the Eolian seamounths: implications for geodynamic evolution of the Southern Tyrrhenian Basin, Earth Planet. Sci. Lett., 74, 187-208.

Boccaletti, M. and P. ManetTi (1978): The Tyrrhenian Sea and adjoining areas, in The Ocean Basins and Margins, edited by A.E.M. NAIRN, W.H. KANES and F.G. STEHLI (Plenuum Press, New York), vol. 4A, 149-151.

Bonasia, V., G. LuOngo and S. Montagna (1976): A land gravity survey of the Aeolian Islands, Bull. Volcanol., 37, 134-176.

Calanchi, N., B. Capaccioni, M. Martini, F. TAssi and L.
VALENTINI (1995): Submarine gas emissions from Panarea (Aeolian Archipelago): distribution of inorganic and organic compounds and inference about source conditions, Acta Vulcanol., 7 (1), 43-48.

Calanchi, N., C.A. Tranne, F. Lucchini and P.L. Rossi (1999a): Geological Map of the Island of Panarea and Basiluzzo (Aeolian Islands), 1:10000 Scale (GNV, Siena).

Calanchi, N., C.A. Tranne, F. Lucchini, P.L. Rossi and I.M. VILLA (1999b): Explanatory notes to the geological map (1:10000) of Panarea and Basiluzzo islands (Aeolian Arc, Italy), Acta Vulcanol., 11 (2), 223-243.

Calanchi, N., A. Peccerillo, C.A. Tranne, F. Lucchini, P.L. Rossi, M. Kempton, M. BArbieri and T.W. WU (2002): Petrology and geochemistry of volcanic rocks from the island of Panarea: implications for mantle evolution beneath the Aeolian Island Arc (Southern Tyrrhenian Sea), J. Volcanol. Geotherm. Res., 115, 367-395.

Chiodini, G. and R. CiOni (1989): Gas geobarometry for hydrothermal systems and its application to some Italian geothermal areas, Appl. Geochem., 4, 465-472.

Chiodini, G., W. D'Alessandro and F. Parello (1996): Geochemistry of gases and waters discharged by the mud volcanoes at Paternò, Mt. Etna (Italy), Bull. Volcanol., 58, 51-58.

De Dolomieu, D. (1783): Voyage aux iles de Lipari. Fait en 1781, Registres de l'Académie des Sciences.

Gabbianelli, G., P.V. Gillot, G. Lanzafame, M. Ligi, D. PostPIsCHL and P.L. Rossi (1986): Controllo strutturale nell'evoluzione vulcanica di Panarea (Isole Eolie), IIV-CNR, Catania, 239.

Gabbianelli, G., P.V. Gillot, G. Lanzafame, C. RomagNOLI and P.L. Rossi (1990): Tectonic and volcanic evolution of Panarea (Aeolian islands, Italy), Mar. Geol., 92, 313-326.

Gasparini, P., G. IAnNaccone, P. ScAndone and R. Scarpa (1982): The seismotectonics of the Calabrian Arc, Tectonophysics, 84, 267-286.

GigGENBACH, W.F. (1987): Redox processes governing the chemistry of fumarolic gas discharges from White Island, New Zealand, Appl. Geochem., 2, 143-161.

Giggenbach, W.F. (1996): Chemical composition of volcanic gases, in Monitoring and Mitigation of Volcano Hazards, edited by R. ScARPA and R.I. TILling (Springer Verlag, Berlin), 222-256.

Giggenbach, W.F. and R.B. Glover (1992): Tectonic regime and major processes governing the chemistry of water and gas discharges from the Rotorua geothermal field, New Zealand, Geothermics, 21, 121-140.

ItALIANO, F. and P.M. NuCCIO (1991): Geochemical investigations of submarine volcanic exhalations to the east of Panarea, Aeolian Islands, Italy, J. Volcanol. Geotherm. Res., 46, 125-141.

LANZAFAME, G. and P.L. Rossi (1984): Evidenze di attività tettonica recente a Panarea (Eolie): implicazioni vulcanologiche, Geol. Rom., 23, 131-139.

Montegrossi, G., F. Tassi, O. Vaselli, A. Buccianti and K. Garofalo (2001): Sulfur species in volcanic gases, Anal. Chem., 73, 3709-3715.

PAnieri, G., R. BARbieri, F. GAMberi and M. Marani (2003): Hydrothermal vents in the Aeolian Arc: effects on benthic foraminifera, in EGS AGU EUG Joint Assembly, 6-11 April, Nice (France). 
Tassi, F., O. Vaselli, B. Capaccioni, J.L. Macias, A. Nencetti, G. Montegrossi and G. Magro (2003): Chemical composition of fumarolic gases and spring discharges from El Chichon volcano, Mexico: causes and implications of the changes detected over the period 1998-2000, J. Volcanol. Geotherm. Res., 123, 105121.
Symonds, R.B., T.M. GeRLach and M.H. ReED (2001) Magmatic gas scrubbing: implications for volcano monitoring, J. Volcanol. Geochim. Res., 108, 303-341. Symonds, R.B., Y. Mizutani and P.H. Briggs (1996): Long-term geochemical surveillance of fumaroles at Showa-Shinzan dome, Usu volcano, Japan, J. Volcanol. Geotherm. Res., 73, 177-211. 